\title{
Evaluasi Penggunaan Antibiotik pada Pasien Anak Rawat Inap di RSD Dr. Soebandi Jember
}

\section{(Evaluation of Antibiotic Use For Pediatric at RSD Dr. Soebandi)}

\author{
Sinta Rachmawati ${ }^{1 *}$, Dewi Khurmi Masito ${ }^{1}$, Ema Rachmawati ${ }^{1}$ \\ $I^{*}$ Fakultas Farmasi, Universitas Jember, Jember, Indonesia. \\ E-mail: sinta.rachmawati@unej.ac.id
}

Article Info:

Received: 08 Januari 2020

in revised form: 18 Januari 2020

Accepted: 08 Juni 2020

Available Online: 06 Juli 2020

Keywords:

Pediatric

Evaluation of antibiotic use ATC/DDD

Corresponding Author:

Sinta Rachmawati

Fakultas Farmasi

Universitas Jember

Jember

68121

Indonesia

email: sinta.rachmawati@unej.ac.id \begin{abstract}
Infection is one of the health problems. It is mostly caused by bacteria. The increased incidence of bacterial infection results in higher antibiotic use. It can lead to antibiotic resistance risk. Antibiotic resistance may occur in pediatric patients. Morbidity, mortality, and high cost of medication are impact of this condition. Evaluation of antibiotic use needs to be done to ensure responsible use of antibiotics. ATCD/DDD (Anatomical Therapeutic Chemicall Defined Daily Dose) method can be used to evaluate antibiotic use quantitatively. ATC classification is a system of grouping active substances according to their location of action and DDD is a measurement system that is connected to the ATC code.The purpose of this study was determining the profile of antibiotic use and measuring quantitative evaluation with ATC/DDD method in pediatric patients. The data was collected by observing the hospital medical record. The results of this study showed that cephalosporin $(46,22 \%)$ was the most used group and cefotaxime $(31,15 \%)$ was the most used type of antibiotic. While, the quantitative evaluation with ATC/DDD method indicated that the highest of antibiotic use was ceftriaxone (11,30 DDD/100 patient days) and the lowest was amikacin $(0,03 \mathrm{DDD} / 100$ patient days).
\end{abstract}

(c) (i) (-)

Copyright () 2019 JFG-UNTAD

This open access article is distributed under a Creative Commons Attribution (CC-BY-NC-SA) 4.0 International license.

How to cite (APA $6^{\text {th }}$ Style):

Rachmawati, S., Masito, D. K., Rachmawati, E. (2020). Evaluasi Penggunaan Antibiotik pada Pasien Anak Rawat Inap di RSD Dr. Soebandi Jember. Jurnal Farmasi Galenika :Galenika Journal of Pharmacy (e-Journal), 6(2), 212-220. doi: 10.22487/j24428744.2020.v6.i2.14976 


\section{ABSTRAK}

Infeksi merupakan salah satu masalah kesehatan. Patogen terbanyak penyebabnya adalah bakteri. Meningkatnya kejadian infeksi bakteri menyebabkan penggunaan antibiotik semakin tinggi. Kondisi ini dapat menyebabkan risiko resistensi antibiotik. Resistensi antibiotik dapat terjadi pada kelompok anak-anak. Morbiditas, mortalitas, dan biaya pengobatan yang tinggi adalah dampak dari kondisi ini. Evaluasi penggunaan antibiotik perlu dilakukan untuk memastikan penggunaan antibiotik yang bertanggung jawab. Evaluasi secara kuantitatif dilakukan dengan metode Anatomical Therapeutic Chemical (ATC)/ Defined Daily Dose (DDD). Klasifikasi ATC adalah sistem pengelompokan zat aktif sesuai tempat aksinya dan DDD adalah sistem pengukuran yang terhubung dengan kode ATC. Penelitian ini bertujuan untuk mengetahui profil penggunaan antibiotik dan gambaran evaluasi penggunaan antibiotik dengan metode ATC/DDD. Pengambilan data dilakukan dengan melihat rekam medis pasien anak rawat inap yang mendapatkan terapi antibiotik. Hasil penelitian menunjukkan golongan antibiotik sefalosporin $(46,22 \%)$ paling sering digunakan. Sefotaksim $(31,15 \%)$ adalah jenis antibiotik yang paling banyak dipakai. Rute pemberian terbanyak adalah secara intravena $(90,82 \%)$. Pada evaluasi kuantitatif dengan metode ATC/DDD, antibiotik dengan nilai DDD/100 patient days tertinggi yaitu seftriakson sebesar 11,30 dan antibiotik dengan nilai DDD/100 patient days terendah yaitu amikasin sebesar 0,03.

Kata kunci: Anak; Evaluasi penggunaan antibiotik; ATC/DDD.

\section{PENDAHULUAN}

Infeksi merupakan masalah kesehatan yang masuk ke dalam sepuluh penyakit terbanyak di Indonesia (Kementerian Kesehatan Republik Indonesia, 2011). Infeksi merupakan kondisi masuknya organisme patogen seperti virus, jamur, atau bakteri ke dalam tubuh dan menyebabkan penyakit. Patogen terbanyak penyebab infeksi adalah bakteri dimanaterapi pengobatan dilakukan dengan menggunakan antibiotik (Grace, P.A. \& Borley, N.R., 2006). Peresepan antibiotik semakin sering karena banyaknya kejadian infeksi bakteri. Banyaknya penggunaan antibiotik dapat menyebabkan resistensi dimana respon bakteri berubah terhadap pemberian antibiotic (World Health Organization, 2018a). Sistem Pengawasan Antimikroba Global (Global Antimicrobial Surveillance System/ GLASS) WHO saat ini menyatakan bahwa sekitar 500.000 ribu orang mengalami resistensi antibiotik di 22 negara (World Health Organization, 2018b). Sedangkan di Indonesia, khususnya di rumah sakit Surabaya dan Semarang, bakteri Staphylococcus aureus telah mengalami resistensi terhadapgentamisin, tetrasiklin, kloramfenikol, eritromisin, oksasilin, dan trimetoprim-sulfametoksazol. Sedangkan Escherichia coli mengalami resistensi terhadap gentamisin, kloramfenikol, trimetoprim-sulfametoksazol, ampisilin, sefotaksim, dan siprofloksasin (Amrin Study Group, 2005).

Peresepan antibiotik tidak hanya diberikan pada orang dewasa tetapi juga pada bayi dan anak. Hasil penelitian di Washington menunjukkan bahwa penggunaan antibiotik pada pasien otitis media akut kelompok anak usia 3-36 bulan sebesar 56\% dan kelompok anak usia 36-72 bulan sebesar 40\%, sedangkan pada pasien infeksi saluran pernapasan atas, bronkitis, dan sinusitis sebesar 10-14\% (Finkelstein et al., 2000). Tingginya peresepan antibiotik akan berpengaruh terhadap tingginya kejadian resistensi. Risiko resistensi antibiotik pada bayi dan anak terjadi karena sistem kekebalan tubuh yang belum berfungsi sempurna, pola perilaku menyebabkan semakin tinggi kemungkinan terpapar oleh patogen, serta penggunaan antibiotik yang tidak ditujukan khusus untuk bayi dan anak (Shea, Florini, \& Barlam, 2002).

Resistensi antibiotik akibat penggunaan yang tidak tepat menimbulkan banyak permasalahan seperti peningkatan morbiditas, mortalitas, dan biaya perawatan kesehatan. Salah satu cara untuk memastikan penggunaan antibiotik yang bijak dan bertanggung jawab adalah dengan mengevaluasi penggunaan antibiotik. Evaluasi kuantitatifdapat dilakukan dengan metode (Anatomical Therapeutic Chemical/Defined Daily Doses)ATC/DDD. Klasifikasi ATC adalah sistem pengelompokan zat aktif sesuai tempat aksinya dan DDD adalah sistem pengukuran yang terhubung dengan kode ATC. DDD merupakan asumsi rata-rata dosis obat perhari pasien dewasa. Pada pasien anak-anak, nilai DDD dapat 
digunakan untuk mengukur perbandingan secara keseluruhan jika suatu kelompok anak sulit diidentifikasi (World Health Organization, 2017).

ATC/DDD dapat menggambarkan peresepan antibiotik di suatu populasi. Beberapa contoh penelitian terkait ATC/DDD pada anak yaitu di RSUP Dr. Kariadi Semarang. Penelitian tersebut menunjukkan hasil bahwa antibiotik dengan nilai DDD/100 patient days tertinggi yaitu seftriakson sebesar 10,6 (Febiana, 2012). Sedangkan, pada penelitian lain di RSUP dr. Sardjito Yogyakarta menunjukkan hasil bahwa antibiotik dengan nilai DDD/100 patient days tertinggi yaitu ampisilin sebesar 10,33 (Carolina, 2014).

Berdasarkan uraian diatas, perlu dilakukan evaluasi penggunaan antibiotik pada anak untuk mengawasi dan memantau penggunaan antibiotik yang bijak dan bertanggung jawab. Penelitian ini bertujuan untuk mengetahui profil penggunaan antibiotik dan mengetahui gambaran evaluasi penggunaan antibiotik secara kuantitatif dengan menggunakan metode ATC/DDD pada pasien anak rawat inap di RSD dr. Soebandi Jember periode tahun 2017dimana RSD dr. Soebandi Jember merupakan rumah sakit rujukan regional daerah wilayah bagian timur yang menangani banyak kasus, salah satunya kasus infeksi pada pasien anak.

\section{METODE PENELITIAN}

Penelitian ini merupakan penelitian deskriptif dengan pendekatan kuantitatif dan menggunakan desain penelitian cross sectional. Studi ini telah mendapatkan persetujuan etik nomor 5644/PL17/LL/2019 dari komisi etik Politeknik Negeri Jember. Penelitian dilakukan di Bagian Rekam Medis RSD dr. Soebandi Jember dimulai pada bulan Desember 2018 sampai Januari 2019. Pengambilan data dilakukan secara retrospektif dengan meneliti rekam medis pasien anak rawat inap yang mendapatkan terapi antibiotik periode tahun 2017.

Populasi pada penelitian ini yaitu seluruh pasien anak rawat inap di RSD dr. Soebandi Jember periode tahun 2017. Teknik yang digunakan dalam pengambilan sampel adalah purposive sampling dimana pengambilan sampel dilakukan sesuai kriteria inklusi pada periode tahun 2017. Adapun kriteria inklusi dalam penelitian ini yaitu pasien anak rawat inap yang mendapat terapi antibiotik dan data rekam medis jelas terbaca serta lengkap meliputi identitas pasien, tanggal Masuk Rumah Sakit(MRS)/Keluar Rumah Sakit(KRS), dan profil penggunaan antibiotik. Sedangkan, kriteria eksklusi dalam penelitian ini yaitu antibiotik tidak memiliki kode ATC dan/atau nilai standar DDD serta pasien anak kondisi pulang paksa, meninggal, atau dirujuk ke rumah sakit lain. Sejumlah 188 data rekam medis memenuhi kriteria inklusi dengan 305 peresepan antibiotik.

Data yang diperoleh ditulis pada Lembar Pengumpul Data (LPD) sebagai data sekunder rekam medis pasien anak rawat inap di RSD dr. Soebandi Jember periode tahun 2017. Data yang dicatat pada LPD meliputi data umum yaitu nomor rekam medis pasien, umur, LOS, status, kelas, ruangan, diagnosis, serta data antibiotik yaitu nama, golongan, dosis, lama pemberian serta cara pemberian antibiotik. Data yang dianalisis meliputi karakteristik pasien dan profil penggunaan antibiotik. Selain itu, data juga dianalisis untuk menggambarkan penggunaan antibiotik secara kuantitatif menggunakan metode ATC/DDD dengan satuan DDD/100 patient days menggunakan rumus :

$$
=\frac{\text { (jumlah gram AB yang digunakan oleh pasien) }}{\text { standar DDD WHO dalam gram }} \times \frac{100}{(\text { total LOS) }}
$$

Kemudian, nilai DDD/100 patient days tiap antibiotik dibandingkan untuk melihat kuantitas penggunaan antibiotik di RSD dr. Soebandi Jember periode tahun 2017. 


\section{HASIL DAN PEMBAHASAN}

\section{Karakteristik pasien}

Dari pengambilan data rekam medik pasien anak rawat inap di RSD dr. Soebandi Jember periode tahun 2017, didapatkan 188 data yang memenuhi kriteria inklusi untuk diteliti. Data inklusi yang telah diolah, dibedakan berdasarkan jenis kelamin, kelompok usia, dan diagnosis penyakit.

Tabel 1.Karakteristik jenis kelamin, kelompok usia, dan diagnosis penyakit

\begin{tabular}{|c|c|c|}
\hline Karakteristik & Jumlah & $(\%)$ \\
\hline \multicolumn{3}{|l|}{ Jenis kelamin } \\
\hline Laki-laki & 100 & 53,19 \\
\hline Perempuan & 88 & 46,81 \\
\hline \multicolumn{3}{|l|}{ Kelompok usia } \\
\hline 0-29 hari (Neonate) & 5 & 2,66 \\
\hline 1 bulan-2 tahun (Infant) & 85 & 45,21 \\
\hline 2-6 tahun (Young Child) & 45 & 23,94 \\
\hline 6-12 tahun $($ Child $)$ & 40 & 21,28 \\
\hline 12-14 tahun (Adolescent) & 13 & 6,91 \\
\hline \multicolumn{3}{|l|}{ Diagnosis Penyakit Primer (ICD 10) } \\
\hline Pneumonia, unspecified (J18.9) & 28 & 14,89 \\
\hline $\begin{array}{l}\text { Other and unspecified gastroenteritis and colitis of infectious } \\
\text { origin (A09.0) }\end{array}$ & 18 & 9,57 \\
\hline Febrile convulsions (R56.0) & 18 & 9,57 \\
\hline Bronchopneumonia, unspecified (J18.0) & 13 & 6,92 \\
\hline Typhoid fever (A01.0) & 12 & 6,39 \\
\hline Otitis media, unspecified (H66.9) & 6 & 3,19 \\
\hline Fever, unspecified (R50.9) & 5 & 2,66 \\
\hline Acute nasopharyngitis [common cold] (J00) & 5 & 2,66 \\
\hline Bacterial infection, unspecified (A49.9) & 5 & 2,66 \\
\hline Epilepsy, unspecified (G40.9) & 5 & 2,66 \\
\hline Status epilepticus, unspecified (G41.9) & 5 & 2,66 \\
\hline Diagnosis penyakit lain* & 68 & 36,17 \\
\hline
\end{tabular}

Tabel 1 menunjukkan hasil karakteristik pasien anak rawat inap. Berdasarkan jenis kelamin, menunjukkan bahwa pasien anak berjenis kelamin laki-laki $(53,19 \%)$ memiliki persentase yang lebih tinggi dibandingkan perempuan (46,81\%). Hasil yang didapat serupa dengan penelitian di RSUD Panembahan Senopati Bantul Yogyakarta yang menunjukkan bahwa pasien anak berjenis kelamin laki-laki sejumlah 54,4\% (Dewi, 2015). Hal serupa juga ditunjukkan pada penelitian di RSD dr. Soebandi Jember tahun sebelumnya dimana pasien anak laki-laki $(51,52 \%)$ memiliki persentase yang lebih tinggi dibandingkan dengan perempuan (48,48\%) (Fatimatuzzahrah, 2017).

Berdasarkan kelompok usia, menunjukkan bahwa pasien anak yang paling banyak menjalani rawat inap di urutan pertama dan kedua masing-masing yaitu 1 bulan-2 tahun (infant) sebesar 45,21\% dan 26 tahun (young child) sebesar 23,94\%. Penelitian serupa di RSUD Ngudi Waluyo Wlingi Blitar juga menyatakan bahwa urutan pertama dan kedua pasien anak yang menjalani rawat inap adalah kelompok usia 1 bulan-2 tahun dan 2-6 tahun (Imaniar, 2018). Kelompok usia bayi (infant) dan anak (young children) memiliki risiko tinggi terkena infeksi bakteri karena sistem kekebalan tubuh yang dimiliki belum berfungsi secara optimal serta tingginya paparan patogen akibat pola perilaku kebiasaan menyentuh dan memasukkan hal-hal disekitar ke dalam mulut. Selain itu, data rekam medis 
menunjukkan bahwa jumlah pasien anak berkurang seiring bertambahnya usia anak. Hal ini dapat terjadi karena semakin bertambah usia anak maka semakin bertambah baik kemampuan tubuh anak untuk melawan paparan patogen penyebab infeksi bakteri (Shea et al., 2002).

Karakteristik diagnosis penyakit disesuaikan dengan kode ICD (International Classification of Disease) 10 versi World Health Organization tahun 2010. Hasil penelitian menunjukkan bahwa lima penyakit yang mendominasi pada pasien anak yaitu pneumonia-unspecified $(14,89 \%)$, other and unspecified gastroenteritis and colitis of infectious origin (9,57\%), febrile convulsions $(9,57 \%)$, bronchopneumonia- unspecified (6,92\%), dan typhoid fever (6,39\%). Penelitian tahun sebelumnya di RSD dr. Soebandi Jember menunjukkan hasil bahwa tifoid, bronkopneumonia, kejang demam, dan pneumonia masih menjadi tren penyakit yang mendominasi pada pasien anak rawat inap (Fatimatuzzahrah, 2017).

\section{Profil penggunaan antibiotik}

Tabel 2. Profil antibiotik berdasarkan jumlah pemakaian dan rute pemberian

\begin{tabular}{|c|c|c|c|c|c|}
\hline \multirow{2}{*}{$\begin{array}{l}\text { Golongan } \\
\text { Antibiotik }\end{array}$} & \multirow{2}{*}{$\begin{array}{l}\text { Jenis } \\
\text { Antibiotik }\end{array}$} & \multirow{2}{*}{$\begin{array}{l}\text { Jumlah } \\
\text { Pemakaian }\end{array}$} & \multicolumn{2}{|c|}{ pemberian } & \multirow{2}{*}{$\begin{array}{l}\text { Persentase total } \\
(\%)\end{array}$} \\
\hline & & & intravena & peroral & \\
\hline \multirow{4}{*}{ Sefalosporin } & Sefotaksim & 95 & 31,15 & - & \multirow{4}{*}{46,22} \\
\hline & Seftriakson & 39 & 12,79 & - & \\
\hline & Sefiksim & 6 & - & 1,95 & \\
\hline & Sefoperazon & 1 & 0,33 & - & \\
\hline $\begin{array}{l}\text { Kombinasi } \\
\text { penisilin dan } \\
\text { enzim inhibitor }\end{array}$ & $\begin{array}{l}\text { Ampisilin } \\
\text { Sulbaktam }\end{array}$ & 60 & 19,67 & - & 19,67 \\
\hline \multirow{3}{*}{ Aminoglikosida } & Gentamisin & 48 & 15,73 & - & \multirow{3}{*}{17,05} \\
\hline & Streptomisin & 2 & 0,66 & - & \\
\hline & Amikasin & 2 & 0,66 & - & \\
\hline \multirow{4}{*}{$\begin{array}{l}\text { OAT (Obat Anti } \\
\text { Tuberkulosa) }\end{array}$} & Isoniazid & 5 & - & 1,64 & \multirow{4}{*}{5,58} \\
\hline & Rifampisin & 5 & - & 1,64 & \\
\hline & Pirazinamid & 5 & - & 1,64 & \\
\hline & Etambutol & 2 & - & 0,66 & \\
\hline Karbapenem & Meropenem & 10 & 3,28 & - & 3,28 \\
\hline Amfenikol & Kloramfenikol & 9 & 2,95 & - & 2,95 \\
\hline Nitroimidazole & Metronidazol & 8 & 2,62 & - & 2,62 \\
\hline \multirow{2}{*}{ Makrolida } & Eritromisin & 2 & - & 0,66 & \multirow{2}{*}{1,32} \\
\hline & Azitromisin & 2 & - & 0,66 & \\
\hline \multirow{2}{*}{ Penisilin } & Ampisilin & 3 & 0,98 & - & \multirow{2}{*}{1,31} \\
\hline & Amoksisilin & 1 & - & 0,33 & \\
\hline \multirow{2}{*}{ Total } & & & 90,82 & 9,18 & \multirow{2}{*}{100} \\
\hline & & 305 & 100 & & \\
\hline
\end{tabular}

"memiliki makna yang sama dengan jumlah pemakaian (dalam persentase)

Terdapat 10 golongan antibiotik yang digunakan dalam terapi pengobatan pasien anak. Golongan antibiotik yang paling banyak diresepkan adalah sefalosporin $(46,23 \%)$. Jika dibandingkan dengan penelitian tahun 2016, golongan antibiotik yang paling sering digunakan tidak berubah yaitu sefalosporin (Fatimatuzzahrah, 2017). Penelitian serupa di RSUD Panembahan Senopati Bantul Yogyakarta periode Januari-Juni 2014 juga menunjukkan bahwa golongan antibiotik terbanyak adalah sefalosporin $(59,8 \%)$ (Dewi, 2015). Hal ini terkait fungsi sefalosporin (spektrum luas) yang dapat melawan bakteri gram positif dan negatif, maupun bakteri anaerob. Antibiotik ini aman digunakan 
untuk pengobatan penyakit infeksi pada anak. Selain itu, sefalosporin merupakan golongan antibiotik yang ditujukan sebagai terapi empiris (terapi pada penyakit yang belum diketahui penyebabnya, tanpa pembuktian secara laboratorik, dan umumnya diberikan saat pengobatan awal) (Ikatan Dokter Anak Indonesia, 2008).

Pada peresepan antibiotik, terdapat 10 golongan antibiotik yang terdiri dari 19 jenis antibiotik. Jenis antibiotik yang paling banyak diresepkan adalah sefotaksim $(31,15 \%)$. Penelitian di RSUD Panembahan Senopati Bantul Yogyakarta periode Januari-Juni 2014 juga menunjukkan tren yang sama yaitu sefotaksim (33,5\%) (Dewi, 2015). Namun, jika dibandingkan dengan penelitian tahun 2016 di rumah sakit yang sama, jenis antibiotik yang paling banyak diresepkan adalah seftriakson $(38,59 \%)$ (Fatimatuzzahrah, 2017). Perbedaan tren penggunaan jenis antibiotik dapat dipengaruhi oleh tren penyakit. Tren penyakit berbeda terjadi pada penelitian tahun 2016 dimana tifoid adalah penyakit yang mendominasi pada pasien anak dan seftriakson paling banyak digunakan sebagai pengobatan tifoid. Sedangkan, pada penelitian ini dan penelitiandi RSUD Panembahan Senopati Bantul Yogyakarta periode Januari-Juni 2014, pneumonia menempati urutan teratas penyakit yang dialami pasien anak dimana sefotaksim paling banyak digunakan sebagai pengobatan pneumonia. Sefotaksim merupakan salah satu antibiotik golongan sefalosporin generasi ketiga. Sefotaksim banyak diresepkan karena memiliki kemampuan untuk melawan sebagian besar gram negatif Bacillus (bukan Pseudomonas), gram positif Coccus (bukan Enterococcus) dan Pneumococcus yang resisten terhadap penisilin. Selain itu, sefotaksim dapat digunakan sebagai terapi pengobatan pada pneumonia, sepsis, dan penyakit yang rentan terjadi akibat infeksi (Aberg, Lacy, Amstrong, Goldman, \& Lance, 2009; Babu \& Vijayan, 2011). Penggunaan antibiotik sefotaksim lebih direkomendasikan untuk anak terutama neonatus dibandingkan golongan sefalosporin yang lain, seperti seftriakson karena sefotaksim tidak memengaruhi metabolisme bilirubin. Selain itu, antibiotik sefotaksim memliki efek samping gastrointestinal yang lebih rendah dibandingkan dengan seftriakson (Dajani, 1995).

Berdasarkan rute pemberian antibiotik, menunjukkan bahwa pemberian secara intravena $(90,82 \%)$ paling banyak dilakukan. Rute pemberian dipilih berdasarkan lokasi infeksi dan efisiensinya. Pemberian antibiotik secara intravena dapat dipertimbangkan pada pasien yang mengalami infeksi sedang sampai berat (Kementerian Kesehatan Republik Indonesia, 2011). Selain itu, pemberian secara intravena juga diperlukan pada saat kondisi pasien tidak sadar, tidak dapat menelan, dehidrasi, atau syok. Rute pemberian secara intravena dilakukan agar antibiotik bisa langsung masuk ke dalam sirkulasi sistemik dan didistribusikan ke jaringan yang terinfeksi. Sehingga diharapkan efek aksi antibiotik dan proses penyembuhan lebih maksimal (Lestari et al., 2017).

\section{Kuantitas penggunaan antibiotik}

Penggunaan antibiotik pada pasien anak rawat inap dievaluasi menggunakan metode ATC/DDD. Evaluasi dilakukan dengan melihat kode ATC (Anatomical Therapeutic Chemical) dan standar nilai DDD (Defined Daily Dose) pada masing-masing jenis antibiotik. Kemudian dilakukan analisis dan perhitungan sehingga didapatkan nilai DDD/100 patient days. 
Tabel 3. Profil kuantitas penggunaan antibiotik berdasarkan metode ATC/DDD

\begin{tabular}{|c|c|c|c|c|c|c|}
\hline $\begin{array}{l}\text { Kode } \\
\text { ATC }\end{array}$ & Jenis Antibiotik & $\begin{array}{l}\text { Total } \\
\text { Gram }\end{array}$ & $\begin{array}{c}\text { Standar } \\
\text { DDD }\end{array}$ & Total DDD & $\begin{array}{l}\text { Total } \\
\text { LOS }\end{array}$ & $\begin{array}{c}\text { DDD/100 } \\
\text { patient days* }\end{array}$ \\
\hline J01DD04 & Seftriakson (iv) & 282,2 & 2 & 141,1 & & 11,30 \\
\hline J01DD01 & Sefotaksim (iv) & 410,63 & 4 & 102,66 & & 8,22 \\
\hline J01CR01 & $\begin{array}{l}\text { Ampisilin } \\
\text { sulbaktam (iv) }\end{array}$ & 281,4 & 6 & 46,9 & & 3,76 \\
\hline J01GB03 & Gentamisin (iv) & 7,26 & 0,24 & 30,26 & & 2,42 \\
\hline J01DD08 & Sefiksim (po) & 10,7 & 0,4 & 26,75 & & 2,14 \\
\hline J01DH02 & Meropenem (iv) & 66,55 & 3 & 22,18 & & 1,78 \\
\hline J04AC01 & Isoniazid (po) & 6,4 & 0,3 & 21,33 & & 1,71 \\
\hline J01XD01 & Metronidazol (iv) & 23,93 & 1,5 & 15,95 & & 1,28 \\
\hline J04AK01 & Rifampisin (po) & 9,53 & 0,6 & 15,88 & & 1,27 \\
\hline J04AB02 & Pirazinamid (po) & 21,45 & 1,5 & 14,3 & 1249 & 1,14 \\
\hline J01BA01 & Kloramfenikol (iv) & 41,35 & 3 & 13,78 & & 1,10 \\
\hline J01FA01 & Eritromisin (po) & 13,6 & 1 & 13,6 & & 1,09 \\
\hline J04AK02 & Etambutol (po) & 15 & 1,2 & 12,5 & & 1,00 \\
\hline J01GA01 & Streptomisin (iv) & 6,25 & 1 & 6,25 & & 0,50 \\
\hline J01FA10 & Azitromisin (po) & 1,35 & 0,3 & 4,5 & & 0,36 \\
\hline J01CA01 & Ampisilin (iv) & 21,8 & 6 & 3,63 & & 0,29 \\
\hline J01DD12 & Sefoperazon (iv) & 6 & 4 & 1,5 & & 0,12 \\
\hline J01CA04 & Amoksisilin (po) & 0,75 & 1,5 & 0,5 & & 0,04 \\
\hline J01GB06 & Amikasin (iv) & 0,42 & 1 & 0,42 & & 0,03 \\
\hline
\end{tabular}

diurutkan dari nilai tertinggi ke terendah; iv=intravena; po=peroral; LOS=Length of Stay

Pada tabel 3, sesuai dengan perhitungan DDD/100 patient days menunjukkan hasil bahwa jenis antibiotik dengan nilai DDD/100 patient days tertinggi yaitu seftriakson sebesar 11,30 dan antibiotik dengan nilai DDD/100 patient days terendah yaitu amikasin sebesar 0,03. Berdasarkan nilai DDD/100 patient days, jenis antibiotik tertinggi dan terendah yang didapat serupa dengan penelitian pada pasien anak rawat inap di RSD dr. Soebandi Jember tahun 2016. Antibiotik dengan nilai DDD/100 patient days tertinggi yaitu seftriakson sebesar 16,90 dan antibiotik dengan nilai DDD/100 patient days terendah yaitu amikasin sebesar 0,12 (Fatimatuzzahrah, 2017). Hal ini menunjukkan bahwa tidak terdapat perbedaan tren jenis antibiotik tertinggi dan terendah pada tahun 2016 dan 2017, meskipun terdapat perbedaan pada nilai DDD/100 patient days.

Nilai DDD/100 patient days pada pasien anak rawat inap menunjukkan kuantitas penggunaan antibiotik sesuai standar WHO. Namun, tidak semua antibiotik dengan jumlah pemakaian tinggi memiliki nilai DDD/100 patient days yang tinggi. Seperti pada penelitian ini, jumlah pemakaian antibiotik tertinggi adalah sefotaksim (Tabel 2), sedangkan antibiotik dengan nilai DDD/100 patient days tertinggi adalah seftriakson (Tabel 3). Hal ini dikarenakan nilai DDD/100 patient days dipengaruhi oleh total Length of Stay (LOS) dan nilai DDD. Semakin tinggi total LOS pada pasien anak menyebabkan semakin rendah nilai DDD/100 patient days pada masing-masing antibiotik, begitupun sebaliknya. Sedangkan, nilai DDD dipengaruhi oleh jumlah total gram antibiotik yang digunakan dimana dosis, aturan pakai, dan lama penggunaan antibiotik pada setiap pasien anak berbeda. Selain itu, nilai DDD juga dipengaruhi oleh standar DDD WHO yang tidak sama antar antibiotik. Seperti pada seftriakson dan sefotaksim, hasil perhitungan jumlah total gram seftriakson sebesar 282,2 gram lebih rendah dibandingkan dengan sefotaksim sebesar 410,63 gram. Menurut standar DDD WHO, seftriakson memiliki nilai standar DDD sebesar 2 dan sefotaksim memiliki nilai standar DDD sebesar 4. Sehingga pada hasil akhir, nilai DDD seftriakson sebesar 141,1 lebih besar dibandingkan dengan nilai DDD sefotaksim sebesar 102,66. 
Dari hasil penelitian ini, dapat diketahui kuantitas penggunaan antibiotik pada pasien anak rawat inap di RSD dr. Soebandi Jember periode tahun 2017. Kuantitas penggunaan antibiotik dapat dibandingkan dengan penelitian serupa di tingkat rumah sakit bahkan antar negara sebagai bahan pertimbangan untuk pengendalian resistensi, perbaikan dalam sistem stok, dan pembuatan pedoman penggunaan antibiotik di rumah sakit (Andrajati, Vlček, \& Wahyudin, 2004; Wardoyo, Suryani, \& Sabrina, 2014). Namun, metode ini tidak dapat digunakan sebagai parameter kerasionalan penggunaan antibiotik karena ATC/DDD hanya mengevaluasi jumlah dan jenis antibiotik (Kementerian Kesehatan Republik Indonesia, 2011). Perlu dilakukan evaluasi lebih lanjut untuk mengetahui penggunaan antibiotik secara kualitatif dengan menggunakan metode Gyssens. Sehingga didapatkan hasil evaluasi secara kuantitatif dan kualitatif sebagai parameter penilaian penggunaan antibiotik yang bijak dan bertanggung jawab pada pasien anak rawat inap.

\section{KESIMPULAN}

Profil penggunaan antibiotik menunjukkan bahwa golongan antibiotik dan jenis antibiotik yang paling banyak digunakan masing-masing adalah sefalosporin $(46,22 \%)$ dan sefotaksim $(31,15 \%)$, serta rute pemberian antibiotik yang paling banyak diberikan adalah secara intravena $(90,82 \%)$. Sedangkan pada evaluasi kuantitas penggunaan antibiotik dengan metode ATC/DDD menunjukkan bahwa antibiotik dengan nilai DDD/100 patient daystertinggi yaitu seftriakson sebesar 11,30 dan antibiotik dengan nilai DDD/100 patient daysterendah yaitu amikasinsebesar 0,03 . Perlu dilakukan penelitian secara kualitatif dengan metode Gyssens untuk mengetahui rasionalitas penggunaan antibiotik dandilakukanwawancara terhadap pihak terkait untuk menguatkan hasil evaluasipenggunaan antibiotik pada pasien anak rawat inap di RSD dr. Soebandi Jember periode tahun 2017.

\section{DAFTAR PUSTAKA}

Aberg, J. A., Lacy, C. F., Amstrong, L. L., Goldman, M. P., \& Lance, L. L. (2009). Drug Information Handbook 17th edition. Hudson: Lexi-Comp for the American Pharmacists Association.

Amrin Study Group. (2005). Antimicrobial Resistance, Antibiotic Usage, and Infection Control : A Self-Assesment Program for Indonesian Hospitals. Jakarta: Directorate General of Medical Care Ministry of Health, Republic of Indonesia.

Andrajati, R., Vlček, J., \& Wahyudin, I. (2004). Assessment of Antibiotics Use after Introducing a Hospital Formulary by ATC/DDD Methodology. Medical Journal of Indonesia, 13(3).

Babu, T. A., \& Vijayan, S. (2011). Cefotaxime-Induced Near-fatal Anaphylaxis in a Neonate : A case report and review of literature. Indian Journal of Pharmacology, 43(5), 611-612.

Carolina, M. (2014). Evaluasi Penggunaan Antibiotik dengan Metode DDD (Defined Daily Dose) pada Pasien Anak Rawat Inap di Sebuah Rumah Sakit Pemerintah Di Yogyakarta Periode Januari-Juni 2013 (Unpublished undergraduate thesis), Universitas Sanata Dharma, Indonesia.

Dajani, A. S. (1995). Cefotaxime use in pediatric infections. Diagnostic Microbiology and Infectious Disease, 22, 105-110.

Dewi, N. P. R. P. (2015). Evaluasi Penggunaan Antibiotika Berdasarkan Metode PPD (Prescribed Daily Dose) dan DDD (Defined Daily Dose) pada Pasien Rawat Inap di Bangsal Anak RSUD Panembahan Senopati Bantul Yogyakarta Periode Januari-Juni 2014 (Unpublished undergraduate thesis), Universitas Sanata Dharma Yogyakarta, Indonesia.

Fatimatuzzahrah. (2017). Evaluasi Penggunaan Antibiotik pada Pasien Anak Rawat Inap di RSD dr. Soebandi Jember dengan Metode ATC/DDD Periode Tahun 2016 (Unpublished undergraduate thesis), Universitas Jember, Indonesia. 
Febiana, T. (2012). Kajian Rasionalitas Penggunaan Antibiotik di Bangsal Anak RSUP Dr. Kariadi Semarang Periode Agustus-Desember 2011 (Unpublished undergraduate thesis), Universitas Diponegoro, Indonesia.

Finkelstein, J. A., Metlay, J. P., Davis, R. L., Rifas-Shiman, S. L., Dowell, S. F., \& Platt, R. (2000). Antimicrobial Use in Defined Populations of Infants and Young Children. Archives of Pediatrics and Adolescent Medicine, 154, 395-400.

Grace, P.A., \& Borley, N.R. (2006). At a Glance Ilmu Bedah. (A. Safitri, Ed.) (3 ${ }^{\text {rd }}$ ed.). Jakarta: Erlangga.

Ikatan Dokter Anak Indonesia. (2008). Buku Ajar lnfeksi \& Pediatri Tropis (2 $2^{\text {nd }}$ ed.). Jakarta: Badan Penerbit Ikatan Dokter Anak Indonesia.

Imaniar, H. (2018). Evaluasi Penggunaan Antibiotik Dengan Metode ATC/DDD Pada Pasien Anak Rawat Inap di RSUD Ngudi Waluyo Wlingi Blitar (Unpublished undergraduate thesis), Universitas Jember, Indonesia.

Kementerian Kesehatan Republik Indonesia. (2011). Pedoman pelayanan kefarmasian untuk terapi antibiotik. Jakarta: Kementerian Kesehatan Republik Indonesia.

Lestari, B., Soeharto, S., Nurdiana, Permatasari, N., Kalsum, U., Khotimah, H., ... Mayangsari, E. (2017). Buku Ajar Farmakologi Dasar. Malang: UB Press.

Shea, K., Florini, K., \& Barlam, T. (2002). When Wonder Drugs Don't Work How Antibiotic Resistance Threatens Children, Seniors, and the Medically Vulnerable. Washington: Enviromental Defense.

Wardoyo, E. H., Suryani, D., \& Sabrina, Y. (2014). Studi Rasionalitas Penggunaan Antibiotika Pasien Rawat Inap di RSUP NTB. Jurnal Kedokteran Unram, 4(9), 64-70.

World Health Organization. (2017). Guidelines for ATC Classification and DDD Assignment 2018 (21st ed.). Oslo Norway: WHO Collaborating Centre for Drug Statistics Methodology.

World Health Organization. (2018a). Antibiotic Resistance.

World Health Organization. (2018b). High Levels of Antibiotic Resistance Found Worldwide, New Data Shows. 